\title{
Realidade e imaginação: uma (re)descoberta do ser em narrativas lygianas
}

\section{Carina Dartora Zonin*}

\begin{abstract}
Resumo: Neste estudo, propomos evidenciar o caráter Abstract: In this study, we consider to evidence the universal da obra de Lygia Bojunga Nunes, universal character of the work of Lygia Bojunga especialmente, nos textos Corda bamba e $O$ sofá Nunes, especially, in the texts Corda bamba and $O$ sofá estampado, tendo, como centro de nossa investigação, estampado, having, as center of our inquiry, the a construção de identidade. Observaremos, para tanto, construction of identity. We will observe, for in such a o percurso dos personagens protagonistas pelos way, the passage of the personages protagonists for the mundos, real e imaginário, no intuito de perceber a worlds, real and imaginary, in intention to perceive the sutileza dos 'contornos' que esses universos mobilizam subtility of the contours that these universes mobilize no sujeito.

in the subject.
\end{abstract}

Palavras-chave: discurso literário; realidade-fantasia; Keywords: literary speech; reality-fancy; identity construção de identidade; imaginário coletivo; leitura construction; imaginary collective; world reading. de mundo.

\section{Introdução}

Com uma linguagem envolvente e criativa, Lygia Bojunga Nunes nos transporta para o universo lúdico e tece aspectos importantes para a vivência da criança, do ser humano em todas as fases da vida. Através de elementos, como a inventividade, a imaginação, a fantasia e o faz-de-conta, os textos que estudaremos permitem uma leitura pelo viés do maravilhoso, um passeio que abre portas para o sonho e para a (re)vivência de fatos passados como forma de se resgatar os valores humanos, num movimento de eterna circularidade. É sobre a capacidade de transgredir o real e de (re)viver num plano fantástico situações que permitem, com mais naturalidade, a vivência do verdadeiro eu do sujeito que teceremos uma leitura das obras Corda Bamba e O sofá estampado.

Como centro de nossa reflexão, procuraremos ver as obras literárias em constante diálogo com a temática central de nosso texto, a saber, a construção de identidade. Para

\footnotetext{
* Carina Dartora Zonin é Especialista em Literatura Brasileira (2008) e em Estudos Lingüísticos do Texto (2005) pela Universidade Federal do Rio Grande do Sul - UFRGS. Dentre suas publicações, destaca-se o artigo intitulado Polifonia e discurso literário: outras vozes que habitam a voz do narrador na obra Ensaio sobre a Lucidez de José Saramago, publicada no Vol. 02 N. 02 da Revista Nau Literária.
} 
iluminar tal percurso reflexivo, utilizaremos textos, como o ensaio de Alice Atsuko Matsuda Pauli (2001), intitulado A travessia de Maria: uma experiência de Leitura de Corda bamba de Lygia Bojunga Nunes, e o texto de Cleide da Costa e Silva Papes (2002), sob o título de A vivência e a invenção no cotidiano em Rosa, minha irmã Rosa, de Alice Vieira e O sofá estampado, de Lygia Bojunga Nunes.

Nesse percurso reflexivo, consideramos a contemporaneidade do estilo narrativo de Lygia e, para tanto, tomamos como norte para dialogar com a questão da construção de identidade a visão de Zygmunt Bauman (2005), em seu texto Identidade. Através dessa leitura, elegemos para a nossa reflexão um conceito que perpassa pela idéia de identidade como algo em constante construção e formação, fortalecendo o eu do sujeito não como algo uno e acabado, mas como um eu fragmentado que se revela pela voz do outro e que tangencia discursos denunciadores de mundos que envolvem esse sujeito e que promove quer a estagnação, quer a emancipação desse eu frente ao outro.

Para tanto, buscaremos repostas para as seguintes questões de pesquisa, de caráter abrangente: mundo imaginário versus mundo real, onde está a nossa verdadeira face? E de caráter mais específico: que caminhos o eu percorre para se encontrar e o que ele nos revela a respeito desses caminhos, mundo real versus mundo imaginário?

Como fontes significativas, as obras Corda bamba e $O$ sofá estampado representam um enfoque bastante recorrente nas obras de Lygia Bojunga, a questão realidade versus fantasia. Através do discurso literário, propomos perceber esse contraponto na trajetória dos personagens protagonistas, revelando uma realidade sem máscaras para cada um dos planos: mundo real e mundo imaginário. Assim, veremos em que universo se estabelece o verdadeiro 'faz-de-conta' e onde reside o verdadeiro eu dos sujeitos, distante de dissimulações e artificialismos. Para isso, fortalecemos a importância do espaço ficcional, da criação literária, como um entrelaçamento de vozes e de mundos que se estendem do particular ao universal, do contexto de vida dos personagens à condição humana em todas as fases da vida. Em seguida, traçaremos as considerações metodológicas que nortearão o desenvolvimento de nossa proposta de estudo.

\section{Considerações Metodológicas}

2.1 Um estudo acerca das obras Corda bamba e $O$ sofá estampado, de Lygia Bojunga Nunes 
Para desenvolvermos nossa proposta de análise, procuraremos estabelecer um diálogo entre as obras Corda bamba e $O$ sofá estampado a fim de perceber os caminhos que a autora faz uso para questionar acerca dos mundos, real e ficcional. Observaremos, sobretudo, a trajetória dos personagens protagonistas e as influências de seu entorno, seja ele através de personagens secundários, seja ele através de instituições, no intuito de perceber as forças que agem sobre a consciência desse eu e o faz oscilar entre os planos, real e irreal, na busca de uma identificação maior consigo mesmo.

Como norte para a investigação, propomos ver em que plano se revela o verdadeiro eu dos sujeitos. Para tanto, consideramos o 'mundo real' como sendo o espaço concreto em que o ser humano está inserido e que produz efeitos próprios do contexto, esse que envolve um momento histórico, político, econômico, religioso e social; o 'mundo imaginário ou fantástico' como o espaço de ficção pura, de sonho, de fantasia, de idealização e que, muitas vezes, contradiz e denuncia o mundo real; ponto esse que centraremos nosso olhar.

Através do contraponto é que teceremos uma leitura acerca da construção de identidade. Assim, nomearemos as reações do sujeito frente aos mundos real e imaginário, como revelação de um 'eu verdadeiro', aquele que suporta traços mais fidedignos do caráter e da personalidade do personagem, percebidos através do percurso de vida do mesmo nas mais diversas situações, ou como um 'eu artificial', esse que, influenciado pelo contexto, assume uma postura estereotipada, própria de uma coletividade que age em favor da preservação e da propagação de determinados costumes e regras que implicam em hierarquia e poder como forma de abafar o verdadeiro eu dos sujeitos e de favorecer o artificialismo próprio de uma 'sociedade líquida', como se refere BAUMAN (2004), em seu texto Amor Líquido:

[...] o cidadão de nossa líquida sociedade moderna - e seus atuais sucessores são obrigados a amarrar um ao outro, por iniciativa, habilidades e dedicação próprias, os laços que porventura pretendam usar com o restante da humanidade. Desligados, precisam conectar-se... Nenhuma das conexões que venham a preencher a lacuna deixada pelos vínculos ausentes ou obsoletos tem, contudo, a garantia da permanência. De qualquer modo, eles só precisam ser frouxamente atados, para que possam ser outra vez desfeitos, sem grandes delongas, quando os cenários mudarem - o que, na modernidade líquida, decerto ocorrerá repetidas vezes (BAUMAN, 2004, p. 7).

Em oposição à liquidez da sociedade, tomaremos as constantes buscas que os personagens protagonistas empreenderão nas suas trajetórias de vida. Assim, pretendemos traçar um perfil do personagem enquanto sujeito e, criticamente, colocar em evidência as sutilezas que envolvem os espaços, real e ficcional, favorecendo o contraponto e a percepção dos artificialismos que impedem a realização do eu verdadeiro e criam um entorno sutil e obscuro. Para tanto, seguiremos nosso percurso, centrando nosso olhar na análise da trajetória 
dos personagens protagonistas das obras em estudo, no intuito de perceber em que plano, seja ele o da realidade, seja ele o da fantasia, ocorre uma maior identificação do sujeito com o seu eu, desvendando, assim, o espaço privilegiado para a construção de identidade.

\title{
30 desvendar de nossa verdadeira face pelos mundos, real e imaginário, sob a luz da trajetória dos personagens Maria, de Corda bamba e Vítor, de $O$ sofá estampado
}

\subsection{O real e o imaginário na construção de identidade}

\begin{abstract}
"Se se quiser falar ao coração dos homens, há que se contar uma história. Dessas onde não faltem animais, ou deuses e muita fantasia. Porque é assim - suave e docemente que se despertam consciências".

Jean de La Fontaine (apud NETTO, 2004, p. 18).
\end{abstract}

Para início de nossa reflexão, tomemos como norte a noção de que o sujeito assume discursos e posicionamentos que reforçam a noção de que estamos em constante transformação, de que somos resultantes de um contexto e que, fragmentariamente, revelamos aquilo que somos, seja expressão de nosso eu na sua mais pura essência, seja expressão de um eu que nada mais é do que representação de modelos e formas de comportamento padronizadas. Desse espaço artificial, surge a necessidade de uma reflexão interior em favor da existência plena do ser humano.

O debate acerca da construção de identidade é uma das tônicas na obra lygiana e perpassa pela noção de que o auto-reconhecimento do sujeito ocorre pelo reconhecimento do outro, sendo esse representativo de esferas, econômica, política, histórica, educacional, que, muitas vezes, abafam ou podam por completo a construção do indivíduo em sociedade. Em palavras de MAGALHÃES (1987), percebemos o viés pelo qual perpassa a construção de identidade:

Na obra de Lygia Bojunga Nunes, a integração no contexto social depende da construção da identidade; esta não é uma dádiva pré-moldada, mas uma conquista penosa através de um processo psicossocial. Um aspecto é indissociável do outro, a interação na sociedade não pode ocorrer independente do outro, a interação na sociedade não pode ocorrer independentemente do conhecimento e assunção de si mesmo. Sendo a personalidade uma construção, nenhuma personagem é estereotipada, não há padronização de pessoas ou comportamentos e, se são referidos, é para enfatizar a importância da liberação de qualquer estado prefixado (MAGALHÃES apud ZILBERMAN; MAGALHÃES, 1987, p. 145-146).

O caminho que a autora traça nas obras em estudo privilegia o imaginário infantil e potencializa seu poder de se enveredar pelo inconsciente no intuito de (re)descobrir mundos e de colorir, magicamente, a realidade na qual estamos inseridos. Ao lermos as obras, vimos o 
mundo sem cor (realidade) e o mundo colorido (fantasia) em constante oscilação, mostrandonos, de maneira universal, uma característica intrínseca ao mundo infantil. Ao nos transportarmos para o mundo da imaginação nos imbuímos da capacidade de ver, somos convidados a 'espiar pra dentro', tal como acontece na obra de Ana Maria Machado, intitulada $O$ menino que espiava pra dentro. Em palavras de Nelly Novaes Coelho acerca do estilo criador de Nunes:

Lygia, em cada livro, enfoca um problema específico da existência humana, através das relações fundamentais que se estabelecem entre o eu e o outro. Em todos eles, a imaginação criadora (lúdico-crítica) é o motor-geratriz da efabulação. A consciência da palavra como construção do real é a pedra angular que sustenta o seu mundo de ficção (NOVAES COELHO apud PAPES, 2002, p. 21).

Através da imaginação, 'mundo do ser', a autora resgata valores importantes de serem compreendidos pelo ser humano, como a perda de pessoas queridas (a morte dos pais de Maria; a morte da avó de Vítor); a valorização dos elos de afetividade (a relação de Maria com Barbuda e Foguinho; a admiração que Vítor sente pela avó); a identificação própria de cada um para com uma profissão (Maria e o circo; Vítor e sua vocação herdada da avó). Através da vivência no plano real, 'mundo do ter', a autora mostra a transfiguração de uma imagem sem cor; mostra o mundo cinza e, muitas vezes, despovoado de vida. É o que vimos nas relações de aprendizado escolar (Maria nas aulas de Matemática; Vítor nas aulas de Português); nos desejos que os outros, os mais velhos, cultivam para Maria e Vítor (os desejos de Dona Maria Cecília Mendonça de Melo e a vontade do pai de Vítor); nos laços de afetividade entrecortados por sentimentos artificiais (Maria e a avó; Vítor e Dalva).

Diferentemente do 'mundo do ser', em que os sentimentos preservam e enaltecem os laços humanos, no 'mundo do ter' esses sentimentos são artificiais, pois são entrecortados por valores estratificados típicos de uma sociedade degradada em que o 'ter' reina absoluto, enquanto que o 'ser' é facilmente descartado. Dona Maria Cecília e Dalva representam personagens desprovidos de personalidade própria e de essência humana. São estereótipos da sociedade capitalista contra os quais se constitui a trajetória de Maria e de Vítor, negando para o mundo do 'ser' uma sociedade padronizada.

Dessa imensidão cinza, surge a trajetória de Maria e Vítor como possibilidade de (re)descoberta do eu, de encontro com a sua essência e, assim, vimos surgirem portas, janelas, ruas como símbolos de vitória, que garantem o 'final feliz' e, em palavras de BETTELHEIM (1980, p. 2006), "assegura à criança que ela não ficará presa permanentemente na imobilidade". Para tanto, o universo da fantasia representa um espaço que potencializa a realização libertária do sujeito. De acordo com ZILBERMAN e CADEMARTORI (apud 
PAULI, 2001, p. 113), ao se referir à personagem Maria, de Corda bamba: "a fantasia tem um efeito reparador: é o universo fantástico que a personagem passa por uma transformação individual que a prepara para o confronto com a realidade e o mundo adulto".

$\mathrm{Na}$ medida em que, através de um mundo fantástico, ocorre o processo de emancipação, concorre, para isso, uma relação de enfrentamento do homem consigo mesmo (Maria e Vítor procuram ver o seu eu), do homem com a natureza (Maria e Vítor enfrentam seus medos) e do homem com a sociedade (Maria e Vítor transgridem os valores impostos pela coletividade).

Por caminhos desajustados e fragmentários, veremos o modo como a autora nos passa a sensação de 'estar-no-mundo', de viver a inserção do humano num espaço confuso e imprevisível. Ao lermos as obras Corda bamba e O sofá estampado, de Lygia Bojunga Nunes, temos a impressão de, literalmente, vivermos numa corda bamba, num fio que nos embala e nos dá o sentimento da incerteza e da eterna busca de si mesmo, própria do ser humano em todas as fases da vida. É uma viagem pelo interior da nossa consciência, é um mergulho nas profundezas mais íntimas e reveladoras do que, essencialmente, chamamos de ser humano. Através de uma leitura acerca das trajetórias de Maria e de Vítor procuraremos resgatar sentimentos e aflições que motivam a constante caminhada.

\subsection{A trajetória da personagem Maria, de Corda bamba}

Uma obra que dilui as fronteiras existentes entre a realidade e o imaginário, Corda bamba, de Lygia Bojunga Nunes, privilegia a emancipação do ser, resgata no seu interior a voz que rompe o mais profundo silêncio e anuncia para o mundo a nossa verdadeira essência. É tendo a interioridade humana como centro da reflexão que a autora tece a trama narrativa e vai colocando-nos na corda bamba que representa o fio pelo qual se sustenta a nossa vida, a nossa vontade de 'ser-no-mundo'.

Diferentemente de Maria, os personagens, tais como Márcia, Marcelo, Foguinho, Barbuda e a Velha da História, personificam o mundo marginalizado que fica sufocado pelo ar cinzento que se espalha e invade a vida e o universo de seres impotentes como demonstração de poder que age sobre uma coletividade e a torna instrumento de dominação. Através desses personagens, veremos o descortinamento do mundo real, as mazelas de um universo de aparências e de interesses individualistas, a denúncia de um sistema autoritário e, totalmente, desvinculado dos valores que regem o ser humano em sua essência. 
Como representantes do poder que se impõe sobre o outro, a avó, Dona Maria Cecília Mendonça de Melo e a professora particular, Dona Eunice, impedem a percepção da identidade de Maria, são seres manipuladores, responsáveis pelo aniquilamento do humano e, sem se dar conta, são, ao mesmo tempo, indivíduos sem rosto, sem face, sem nada que os individualize e os tornem pessoas-chave na construção de um mundo mais humano. São representações do mundo real na sua mais expressiva forma: são as que estão imersas no tempo em que o capitalismo centraliza as crenças e emoldura ações e indivíduos como receptadores e reprodutores do sistema.

Em outro plano, ocorre o desenvolvimento da trajetória de Maria, personagem central da narrativa e foco de observação neste estudo. É no mundo da imaginação que a vimos traçar o rumo que a levará ao encontro com o seu eu, na sua mais pura essência, no espaço psíquico que Maria irá se refugiar das mazelas que a cercam no mundo real. Do mesmo modo, através da invenção conquista o sentimento de liberdade que a faz crescer enquanto sujeito e a torna capaz de traçar o seu caminho, de abrir portas e janelas, de arrumar cada novo espaço ao seu gosto, de ser alguém capaz de escolher, capaz de viver a sua vocação.

Maria é a única personagem que possui mobilidade e consegue transpor a fronteira que delimita os espaços da opressão e da liberdade, é o ser em ação, é a força que (re)inventa o mundo e (re)inventa o seu eu, querendo abranger o outro, querendo o engajamento de todos nós nessa viagem que permite transpor mundos e revelar o verdadeiro eu dos sujeitos. $\mathrm{Na}$ desenvoltura do seu eu, através do sonho e da fantasia, revelam-se elementos que fortalecem um rito de passagem e têm sentido libertador: porta, janela, corda bamba, barco, arco, fio, cores, mar, chuva, etc.

Maria reconhece o espaço em que está inserida como impróprio para a sua ascensão, percebe o distanciamento dos laços de afetividade e que, no mundo da avó e das aulas particulares restam, apenas, portas fechadas. Para ela, Quico, Barbuda e Foguinho são seres que, no universo real, motivam sua constante busca por si mesma, pela sua história, pelo seu passado que guarda traumas e perdas que a anulam enquanto sujeito. Esse efeito negativo, da anulação de si mesma, nasce de um contexto que a quer manipular e que a vê como recompensa, como ser objeto e não como ser humano. Maria se inspira nos laços de afetividade para se (re)encontrar e para revelar o aprisionamento que o seu eu vive no mundo real. Ela não desiste e busca resgatar no imaginário momentos importantes para a sua emancipação enquanto sujeito no mundo:

Foi no dia do teste que veio um telegrama pra Quico: Chegamos na segunda-feira para buscar você beijos mamãe papai. Quico ficou prosa: não era todo o mundo que recebia telegrama. 
Mas Maria não gostou de ver Quico indo embora. Depois do almoço, quando foi pra escola fazer o teste, não conseguia prestar atenção nas perguntas. [...] Teve entrevista com diretora, conversa com orientadora, e mais isso e mais aquilo, e o pensamento sempre correndo atrás de Quico, Barbuda e Foguinho (todo o mundo indo embora), correndo pro corredor comprido e abrindo tudo que é porta (NUNES, 1992, p. 108-109).

A trajetória de Maria abrange espaços representativos de seu aprisionamento e de sua libertação. O mundo real é o do artificialismo, é onde as instituições lançam sobre o humano o seu poder de manipulação que tende a aniquilação do ser. Nesse universo, o aprendizado de Maria no circo e a educação zelada por seus pais não são valorizados; é o espaço contagiado pela capacidade de não ver em Maria qualquer potencial. Em conversa com Barbuda, vimos a aflição de Maria, a anulação do seu eu pelo mundo real, aqui representado pela instituição escolar e pelo comportamento da avó, e, ainda o sentimento de Barbuda abafado pelo espaço pelo qual está imersa e não consegue reagir:

- Alô, Maria? Você ainda não me contou nada do que você tem feito, minha filha. Tua avó levou você na escola?

- Levou. Logo no dia seguinte que eu cheguei.

- E daí?

- Elas acharam que eu tô atrasada pra minha idade.

- Atrasada? Atrasada como? Você não mostrou como você escreve, como você lê, como você desenha, como você equilibra?

- Bom...

- Você não contou como é que todo o dia a sua mãe tomava a sua lição, fazia você estudar?... Alô?... Alô?... Maria...! Alô!

$[\ldots]$

- Elas falaram lá na escola que na minha idade eu já tinha que saber fatoração, já tinha que saber múltiplos e divisores, já tinha que... [...] Diz que com dez anos precisa, sim. Então a minha avó chamou uma professora particular para me dar aula (NUNES, 1992, p. 32-33).

Sendo assim, as aulas ministradas pela professora particular ilustram sentimentos e reações promovidos por uma relação de ensino-aprendizagem totalmente aniquilante. Maria, nesse mundo, é um ser-objeto, é um não-ser, uma ausência de si no mundo e, por isso, não consegue se mostrar, não encontra o fio que a levaria a vida, a um aprendizado em vida, é um momento que traz a sensação do medo e da impotência. Maria não tem aonde botar o pé, não tem um espaço acolhedor, não tem um mundo que a veja como ser humano e necessita se ausentar desse universo e (re)criar outro capaz de trazer à tona sua essência. Maria é a mais pura representação do mundo fantástico, é o canário que está preso numa gaiola que não comporta sua ânsia por liberdade:

O canário na gaiola cantou; Maria olhou. A gaiola estava pendurada na janela, batia sol no canário, ele parou de cantar e começou a pular pra um lado e para outro, será que ele queria sair? Mas a porta estava fechada, uma gaiola de nada, como é que prendiam ele assim apertado com tanto lugar pra voar? [...] (NUNES, 1992, p. 52). 
Nessa perspectiva, no capítulo em que a autora nos conta sobre a aula particular, somos levados a sentir, através de Maria, as limitações de um mundo cheio de vícios que ditam comportamentos sistemáticos e rotineiros, que anulam qualquer possibilidade de demonstração voluntária do eu verdadeiro:

A professora se chamava Dona Eunice, e foi só a Dona Eunice e Maria sentarem pra dar aula que o cachorro se esparramou debaixo da mesa. Maria encolheu as pernas. Dona Eunice botou o pé em cima do cachorro. O cachorro suspirou. A aula começou.

- Maria, você está fraca em tudo que é matéria. Matemática então nem se fala. Vamos ficar só na matemática hoje. - Abriu um livro. [...] Vamos construir a 'árvore' dos divisores de um número natural, por decomposição. - Pegou o caderno de Maria e começou a fazer uma divisão na página. [...] - Mas antes você me diz se esses números são divisíveis por três, por dez e por mil. [...] Maria fez força pra pensar. Dona Eunice levantou a mão, sacudiu o braço, e tudo quanto é pulseira foi pro cotovelo, uma esbarrando na outra. Quando Dona Eunice sacudia o braço daquele jeito é porque estava meio sem paciência, era melhor escrever logo uma coisa, mas o quê? Uma coisa qualquer, depressa, correndo. Escreveu. Vai ver estava tudo errado (NUNES, 1992. p. 51-53).

Nesse cenário, o cachorro personifica a imagem desse mundo que, constantemente, impõe medo aos indivíduos que estão nele imerso, impedindo de os mesmos se mostrarem enquanto seres humanos potenciais. Maria estava sob o efeito do medo: medo de falar, de pedir, de contrariar, de ser ela mesma, nem sequer podia se mexer senão ela batia no cachorro e ele começava a latir: "Ai, como a perna tava esquisita! Como ia ser bom sacudir ela bem. [...] Mas de que jeito? Se sacudia a perna, ela batia no cachorro [...] E se a perna batia..." (NUNES, 1992, p. 54-55).

Maria não sabe como participar desse mundo cheio de regras e de boas maneiras que a fazia se sentir paralisada, deixando-nos ver o quanto são desconexos os métodos de ensinoaprendizagem adotados por Dona Eunice, nada acrescentam à interioridade da personagem, são, antes de tudo, expressões de ordem e tentativa de dominação, não reconhecem a bagagem de conhecimentos e experiências que a menina já traz consigo:

Maria não conseguia mais se lembrar o que é que ela tinha que fazer com o menor múltiplo. Desatou a morder o lápis [...]

- Temos tempo, Maria, temos tempo. Endireita as costas. Atenção com a coluna. Não morde o lápis desse jeito, estraga ele todo. E olha só a sua boca, o lábio tá preto! tudo sujo de casca de lápis.

Maria passou a língua no lábio.

- Não faz isso, menina, não faz isso!

Maria ficou de língua espichada sem entender o que é que ala não podia fazer (NUNES, 1992, p. 56-57).

Maria, em sua trajetória, representa o mundo do ser em ascensão, diferentemente de Barbuda, Foguinho e a Velha da História que têm luz interior, mas acabam na escuridão do mundo real, na mesma nuvem cinza que povoou a trajetória de seus pais, Márcia e Marcelo, 
representantes da coletividade, que tem o brilho ofuscado pelos constantes atritos que sofrem no mundo das aparências, o qual já tomou conta de Dona Eunice e de Dona Maria Cecília.

A passagem de Maria para o universo fantástico ocorre através dos sonhos e Quico é o que promove o início dessa viagem que, aos poucos, levará Maria a um auto-reconhecimento de si no mundo. O sonho é uma representação da imaginação e da fantasia e permite que retornemos ao nosso interior com a liberdade de ver tudo o que nos motiva. O que nos dá medo, o que nos angustia, é o momento de (re)visitar esses sentimentos com um novo olhar, um novo espírito embalado por uma atmosfera que potencializa a libertação do humano, o aprendizado emancipatório do eu no mundo.

É através de uma janela em forma de arco, diferente de todas as outras, que Maria chegará ao andaime para presenciar o encontro de seus pais, o momento em que eles se conheceram, marcando o início de uma união de amor, com força para vencer as repressões de Dona Maria Cecília, com a luz necessária para trazer ao mundo Maria e apresentá-la ao circo, espaço que a cativou e que foi palco da morte de seus pais, mostrando a ela a rudeza do mundo real, a aspereza com que as relações se constroem, a falta de valorização do humano e de condições dignas de trabalho. Maria é a esperança de libertação, de poder (re)escrever a história de sua família com uma tonalidade menos áspera e mais humanitária.

Aos poucos, Maria vai revelando o seu passado no corredor comprido e cheio de portas, cada uma de uma cor. Através da porta branca, ela avistou o encontro de seus pais, o momento em que eles se conheceram; da amarela, ela viu seu nascimento, o momento que simboliza o 'ser-para-a-vida', o princípio de sua trajetória em sociedade. Com Maria nasceu a esperança, pois ela é a força de vida que veio transformar o mundo, dar luz e cor ao que antes permanecia sob o efeito da sombra, ela é porta-voz da vida em movimento, do sopro de vida que ocorre, com força e expressividade, no mundo da imaginação, do sonho e da fantasia.

Através da porta de cor cinza surge o momento em que foi seqüestrada pela avó, ficando separada de tudo o que mais amava: os pais e o circo; na porta sem cor, Maria revive a comemoração de seu aniversário de sete anos. Nesse episódio, a vida pára! O estereótipo da avó é descaracterizado por um comportamento pervertido. Dona Maria Cecília representa a voz materialista que se sustenta pelos valores de troca: ela 'compra' um brinquedo humano para a sua neta. Aqui temos o momento em que o 'vazio' deixado pela avó materna é preenchido por um estranho: a Velha da História. Essa que personifica o papel da avó no imaginário infantil através da contação de histórias. Na porta azul, ela se reencontra com seus pais depois de ter sido tirada do circo por sua avó e se insere no mundo do circo através da corda-bamba. Ao completar dez anos, Maria é o seu próprio espelho, é o momento de 
enfrentar seus medos e de se (re)encontrar consigo mesma. A imagem de Maria refletida no seu passado é, agora, a mesma do presente, a que está preparada para olhar para o vivido e superar traumas, medos e mistérios, criando condições para inserir-se no presente e projetar o seu futuro. É o momento de abrir a porta vermelha e (re)ver a morte de seus pais, é o momento em que Maria se depara com a perda, é chegada a hora de abrir sem medo as portas e janelas de sua vida. Através da imaginação, Maria abre as portas e encontra sua identidade mais íntegra, é o seu eu na mais pura essência, distante da estagnação, própria do mundo autoritário, é a corda-bamba, é a vida em constante mutação e crescimento:

O tempo vai passando, mais portas vão aparecendo, e Maria vai abrindo elas todas, e vai arrumando cada quarto, e cada dia arruma melhor, não deixa nenhum cantinho pra lá. Num quarto ela bota o circo onde ela vai trabalhar; no outro ela bota o homem que ela vai gostar; no outro os amigos que ela vai ter. Arruma, prepara, prepara: ela sabe que vai chegar o dia de poder escolher (NUNES, 1992, p. 125).

Por meio da invenção e da fantasia, Maria vai em busca de sua identidade perdida e é nesse mundo mágico que encontra um efeito reparador, capaz de proporcionar uma transformação individual que a prepara para o confronto com a realidade e a projeta para o futuro, sem os medos, os traumas e as constantes opressões que a impediam de falar, de se ouvir, de se ver: "E esse tempo todo a Maria ficou assim: calada, só pensando" (NUNES, 1992, p. 19). Entre o mundo real e o imaginário, Maria vai criando forças para (re)viver seu passado. No mundo real, Maria vê o aprisionamento de sua vida e as constantes limitações dos que admira, principalmente, de Foguinho, Barbuda e a Velha da História. No mundo da imaginação e do sonho, Maria encontra portas e janelas abertas, é nesse espaço que adquire força para se ver enquanto sujeito.

Nesse espaço fantástico, tudo se revela sem máscaras. É o mundo da essência, é o interior de Maria agindo sob sua capacidade de ver, é a vontade de seguir sua trajetória sem medo, de projetar o futuro tendo a certeza de que chegará o dia de poder escolher, de que mais portas e janelas se revelarão no seu caminho, ou melhor, no 'corredor comprido', na 'cordabamba' que nada mais é do que a linha do tempo, a linha da vida, da nossa vida: "Era uma porta diferente de tamanho e de feitio, diferente de pintura também: parecia que estavam experimentando cor: tinha uma porção de pinceladas, cada uma de uma tinta. Maria abriu a porta de leve e bem devagar. Mas sem medo. Era um quarto vazio" (NUNES, 1992, p. 123).

Lygia Bojunga Nunes nos inclui no universo criado em Corda bamba e nos diz que estamos em curso, que cada acontecimento em nossa vida é um aprendizado e é, acima de tudo, uma passagem para outro e mais outro, infinitamente. Através da trajetória da personagem Maria, transportamo-nos para o interior do humano e damos um colorido 
diferente para tudo o que nos foi (im)posto, somos levados a (re)construir o percurso de nossa vida através da imaginação e do sonho, (re)inventando o mundo e os sujeitos, ambos capazes de traçarem o fio que nos levará a nossa verdadeira face, colocando-nos, efetivamente, no percurso da emancipação do eu no mundo, frente a si e frente ao outro.

\subsection{A trajetória do personagem Vitor, de $O$ sofá estampado}

Num tempo em que os animais falavam, tinham personalidade e externavam seus desejos e sentimentos, Lygia Bojunga potencializa vivências que vão desenrolando situações universais, através do tatu Vítor. Às vezes, a vontade de falar cede espaço ao medo, à ansiedade, a sentimentos que nos dispersam de nossos objetivos; às vezes por querer teimar viver num mundo com o qual não concordamos é que o desmascaramos e, ao correr para nos escondermos, é que nos encontramos.

Na obra $O$ sofá estampado, centramos nosso olhar na trajetória de Vítor. Essa perpassa os mundos, real e imaginário, e deixa traços significativos que nos remetem aos conflitos dos homens, pois dizem muito de nossas dúvidas, de nossos medos, de nossos sentimentos, sejam eles de revolta ou de cumplicidade, mapeando as grandezas e as mazelas que edificam o mundo; esse que vamos buscar lá no interior do sujeito e que tanto pode ser um espaço em que sobrevive o real quanto um lugar em que reina a imaginação e a fantasia.

Vítor representa um personagem que se move pelos seus sentimentos, por impulsos ora provocados pelo medo e pela ansiedade, ora ocasionados pelo desejo e pelo encantamento. O desprendimento do mundo real, a vontade de sumir, de não viver mais neste tempo, é ocasionado por sentimentos opressivos e nos mostra o quanto nos privamos de nós mesmos quando nos encontramos na 'obrigação-de-fazer'; na 'obrigação-de-ser': "Não era tatu de fazer manha; não era tatu de malcriação; e mesmo quando não estava a fim de uma coisa ficava sempre meio sem jeito de dizer não" (NUNES, 1992, p. 25).

É através do enfrentamento dessa realidade que Vítor simboliza a força contrária, aquela que reage, transforma e que garante a construção de sua própria história, desvendando a ação de criar sobre um mundo que vem se petrificando em todos os aspectos. Pelo viés da imaginação é que Vítor denuncia a urgência de se construir um mundo mais verdadeiro e buscando, sobretudo, a si mesmo, Vítor desvenda as mazelas que escondem o verdadeiro eu dos sujeitos.

Vítor representa a voz repreendida pela sociedade através dos tempos, é o grito que está aí, pronto para despertar consciências. Através da invenção, ganha a dimensão de uma 
denúncia alarmante que o coloca como porta-voz de uma coletividade que vê as mazelas de um mundo materialista, que valoriza a mídia, o artificialismo, o consumo, a aparência e o capital; tudo isso posto em prejuízo do ser e da valorização da vida. Vítor é a naturalidade perdida e que, aos olhos do mundo moderno, é inconcebível:

A Dona-da-casa tinha a mania do combina: o sapato precisava combinar com o vestido, 'ih, que horror, esse vestido não combina com a poltrona, deixa eu ir lá trocar de roupa antes de vir me sentar', a cortina tinha que combinar com o tapete, a poltrona com o sofá, a flor na jarra tinha que combinar com os dois, e se uma coisa não combinava com a outra a Dona-da-casa tinha dor de cabeça, e no dia que a Dalva anunciou esse é o meu namorado, o choque do buraco foi quase tão grande quanto o choque do descombina: se tinha coisa que não combinava era o Vítor com a Dalva; e pior: o Vítor com o sofá estampado (NUNES, 1992, p. 15).

Nesse contexto, Vítor é visto como objeto, como uma peça que pode ser ajustada ou, simplesmente, descartada: o mundo do ter aniquila o ser. Tomados pelo deslumbramento aparente que envolve o mundo moderno, personagens como a Dona-da-casa, Dalva, Ipo, Pôzinha e o pai de Vítor compõem o que BAUMAN (2004) nomeia como sendo a 'liquidez da sociedade'.

Através do diálogo que o pai estabelece com Vítor, vimos sobressair indícios de uma sociedade contaminada pelo vírus do consumismo, que acredita na aparência, na renovação exterior sem se preocupar com o ser humano. É, literalmente, um ser encoberto por máscaras descartáveis que revelam a mesquinhez humana, essa que não deixa ver o outro enquanto sujeito que tem idéias próprias, mas que o concebe como mais um produto que deve responder às crenças da sociedade capitalista e que, significativamente, provoca em Vítor a vontade de tossir e os engasgos como representação de uma força contrária e que repulsa os valores cultuados pelo mundo moderno:

Toma, Vítor, tudo que você tem que fazer está aqui escrito: procura esse pessoal, mostra esse folheto colorido, explica que essa história de consertar carapaça que vai ficando velha ou que arranha ou que quebra é coisa do passado, já não se usa mais.[...] E explica bem pra eles tudo que é vantagem da carapaça de plástico: quebrou? joga fora e compra outra; rachou? joga fora e compra outra; sujou? joga fora e compra outra.

$[\ldots]$

- Mas eu não gosto de carapaça de plástico: me dá aflição. [...] Eu queria fazer uma coisa que eu gosto! - Mas o 'que eu gosto' já não conseguiu mais sair, deu marcha à ré, começou o tal engarrafamento na garganta do Vítor e tudo que ele queria dizer acabou ficando pela metade (NUNES, 1992, p. 55-56).

Assim, num mundo coisificado tudo é descartável. Segundo os estudos de PAPES (2002, p. 9), podemos ler o mundo real como aquele em que concentra imagens vazias, que se propagam num tempo fragmentário, que glorificam o consumismo desmedido, potencializam o desapego e fragilizam, cada vez mais, o ser: 
Do Rio Grande ao Amazonas tudo que é telespectador começou a reclamar: 'Puxa, esse tatu tá enchendo! toda a hora a gente dá de cara com ele na tevê'. Quando o Vítor voltou na Z, a Dona Popô mandou um recado: 'Não tenho mais tempo pra falar com ele. Nem vou ter. O Vítor procurou outras agências: em vez de mandarem ele entrar, mandavam recado: 'Ele não interessa mais: a tevê já espremeu tudo que ele podia dar' (NUNES, 1992, p. 98).

Nesse espelhamento das relações sociais, vimos a denúncia de uma sociedade que se sustenta pelo valor de uso, de um modo degradado. Desse meio, proliferam indivíduos problemáticos que jamais atingirão a autenticidade de seres humanitários. É um espaço impróprio para se encontrar a verdadeira face, é um mundo de máscaras e de artificialidades que coopera para a geração de sentimentos de repulsa que, por sua vez, impulsionam os seres a buscar outros mundos, a cavar e cavar. Em palavras de Lucien Goldmann:

[...] toda a relação autêntica com o aspecto qualitativo dos objetos e dos seres tende a desaparecer, tanto das relações entre os homens e as coisas como das relações inter-humanas, para dar lugar a uma relação mediatizada e degradada: a relação com os valores de troca puramente quantitativos (GOLDMANN apud PAPES, 2002, p. 9).

O mundo real é o espaço artificial em que reinam objetos e coisas. Não há espaço para a revelação do humano em sua essência; é o mundo de aparências, de beleza exterior, do combinar isso com aquilo, quer dizer, o sofá com outras coisas. O sofá é a personificação do mundo coisificado, do espaço da imobilidade e da reificação do material em que o ser é minimizado e os personagens se projetam como atores num palco. É o mundo do espetáculo em que sobrevivem espectadores, seres-objetos imersos num universo de sombras: "É pequeno, tem só dois lugares. E fica perto da janela. Pro sol não desbotar o estampado, a Donda-da-casa fez uma cortina branca, fininha e toda franzida; no fim de atravessar tanto pano, a luz entra cansada na sala, clareando tudo de leve" (NUNES, 1992, p. 9).

Enquanto que no mundo real sobrevivem as máscaras, no mundo da imaginação encontramos os 'eus' desprovidos de quaisquer envolturas; é o lugar que permite a (re)descoberta de nossa verdadeira face, é um espaço simbólico que fortalece a contraposição ao mundo moderno, que distingue a sutileza dos contornos que tendem a abafar o artificialismo dos seres que se deixam tragar pelo espaço real e nos faz ver, no dizer de Michel Foucault (apud PAPES, 2002, p. 7), que “nossos eus são a diferença das máscaras”. É nessa dispersão do que somos e fazemos que buscamos traçar os percursos pelos quais perpassa a construção de nossa identidade.

Vítor representa a força que luta por um horizonte de liberdade e que se vê, muitas vezes, sem saída. Nesse labirinto, a imaginação é que garante a fertilidade do pensamento e ações que mostram como ainda é possível um resgate interior. A vontade de sumir, de se esconder num buraco representa uma passagem para a renovação; os engasgos e a vontade 
incessante de tossir são indícios de profunda contrariedade e desconexão: Vítor não pertence ao mundo moderno. Vítor é um ser sem máscaras, é a naturalidade perdida, é, acima de tudo, alguém que acredita na sua força interior e a usa em benefício da invenção de mundos, é a expressão que, mesmo imersa num mundo de artificialismos, encanta-se pelo que, embora sufocado, ainda tenha de belo: "O Vítor não tirava o olho da Dalva. Nossa! Que coisa mais linda [...] O Vítor queria entender por que tanta confusão, tanto empurrão, mas só dava pra entender a beleza da Dalva" (NUNES, 1992, p. 59-60).

Dalva representa o mundo exterior, aquele que valoriza a beleza aparente e que reproduz, facilmente, os valores cultivados pelo mundo moderno, pelo mundo visual. É a personagem que merece destaque por assistir televisão praticamente todo o tempo; é a personagem que combina, aos olhos da Dona-de-casa, com o sofá estampado: Vítor chega a pensar que Dalva e o sofá estampado são um só. Dalva só tem tempo para ouvir e reproduzir, não tem o gosto pela leitura, muito menos percebe e/ou valoriza o sentimento interior, é fruto de um tempo que atrofia as relações sociais, que a desvincula de seu próprio interior e a impede de estabelecer contatos interpessoais.

Encantado pela beleza, que era acessível à sua compreensão, Vítor procura construir elos de afetividade, querendo conquistar a admiração de Dalva, mas os olhares estão voltados para mundos diferentes. Vítor é o choque do 'descombina', é o mundo da invenção que não pode ser ouvido, que não existe num mundo de figurantes que aguarda, ansiosamente, o grande espetáculo da (re)produção e, mais uma vez, o tatu é incompreendido: não consegue falar, não tem espaço para ser ele mesmo e, então, decide cavar, cavar e sumir. Vítor é o homem da idéia, enquanto que Dalva é objeto da passividade.

Magicamente, a autora busca na despersonalização dos personagens um modo de espelhar as relações entre humanos. O apego de Dalva à televisão, veículo condicionador de atitudes e comportamentos na sociedade contemporânea e, em muitos casos, ocasionador da dependência total do indivíduo, tem uma abrangência vasta e manipula verdades que se instauram à massa, que acaba vidrada na tela, deixando a passividade tomar conta do ser de ação. O espaço da televisão e do sofá estampado, de Dalva e da Dona-da-casa, simboliza o mundo real, capitalista e consumista, aquele que desfaz o humano se esse não se libertar através de outros mundos:

O Vítor sentou no sofá estampado e ficou olhando com força pra Dalva. Depois de muito tempo ela percebeu e deu uma piscadinha pra ele.

- Você recebeu a minha carta, Dalva?

- A-do-rei.

- E daí? 
- O quê?

- Dalva, olha pra mim.

- Psiu.

- A gente tem que falar do casamento.

- Quando acabar a novela.

O Vítor foi ficando nervoso; foi sentindo na unha uma vontade de cavar [...] Cavou tão fundo que foi dar no tempo que ele era tatu-criança (NUNES, 1992, p. 17-20).

Vítor inicia a cavação de um túnel que o levará ao passado, ao tempo de infância, a fase em que se depara com o início de seu engasgo, de seu medo, de sua tristeza, de suas frustrações; tudo isso desencadeando numa tosse aflitiva que representa sua vontade de desaparecer. Vítor personifica a luta do homem contra o vazio que vai tomando conta do real, é um ser-consciente que rejeita a degradação, o não-ser. Vítor é o personagem da invenção e do fazer, marcando a sua volta ao passado através da imaginação, de sua força interior que o faz cavar e cavar até construir um túnel que o permite regredir no tempo e na história a fim de resgatar a sua dignidade e atingir a sua essência. Um túnel cavado para dentro de si mesmo a fim de atingir o seu interior para não anular-se em sua individualidade, libertando-se da alienação que povoa o mundo de Dalva. É nesse voltar ao passado que Vítor segue sua trajetória com o entendimento necessário para se ver como ser humano autêntico, com sua identidade preservada e capaz de prosseguir na construção de seu projeto de vida:

Ele tomou até um susto: tinha vindo embora sem nunca ter visto o mar [...] depois é que ele explicou na calma pro pai que agora ele sabia o que queria 'e eu não quero mesmo vender carapaça, viu, pai?’. E falou do trabalho da Vó. Contou que queria fazer uma coisa parecida. E o bom foi que ele falou tudo sem se engasgar e nem tão baixinho assim... (NUNES, 1992, p. 107).

Liberto do aprisionamento, Vítor é o personagem que anuncia a grandeza na qual se empenha a arte. Sendo ela invenção da realidade, é, na trajetória do nosso personagem, que observamos a realização do que nos diz SARTRE (apud PAPES, 2002, p. 13) acerca da finalidade última do ato criador: "recuperar o mundo, mostrando-o tal como ele é, mas como se tivesse origem na liberdade humana".

Um dos elementos simbólicos que favorece a ascensão de Vítor é a escada. Subir seus degraus é ir em busca da liberdade; a escada que brilha no fim do túnel aparece e desaparece à visão de Vítor porque está ligada ao seu interior. O seu surgimento marca momentos em que Vítor sente a possibilidade de ascensão e de caminhar em sua direção. Subir degrau por degrau simboliza a emancipação do eu frente ao outro; são os passos que Vítor necessita dar para a percepção do seu eu enquanto 'ser-no-mundo', que segue o percurso em direção a construção de sua identidade. Vítor volta a ver luz através da escada no momento em que conseguirá se libertar do interior de sua carapaça. Por meio de um sonho cinzento, Vítor se 
vê iluminado para ir de encontro à escada. Através da recordação de um tempo opressor, Vítor reage e busca no seu interior a força que o levará a se encontrar como sujeito.

Através desse processo de libertação, Vítor vê, ao invés da Mulher sem rosto e do lenço de seda, o Inventor e a mala que pertencia a sua avó, simbolizando o momento de poder escolher. Vítor não ficou com a Mulher sem rosto e nem foi embalado pelo lenço de seda, pois não pertence ao mundo sem identidade e capitalista. Pertence, sim, ao mundo dos valores e dos laços de afetividade: resgata-se o valor do ser sobre a coisa e o ser desponta renovado.

Um dia Vítor arrumou a mala e foi para a Amazônia, foi, efetivamente, seguir o caminho que acreditava e colocar em prática as ações regidas pelos valores que cultivava dentro de si. Nessa viagem, Vítor foi viver sua identidade, sua vocação de transformar o mundo, de lutar pela preservação da vida, de mostrar ao mundo que chegou o momento de ser integral. Em palavras de PAPES:

No caminho da liberdade, Vítor atingiu a sua saída: cavando, cavando encontrou a escada, subiu e saiu do túnel para a nova vida - a escavação. Neste termo encerra-se o sentido da busca - 'tirar para fora da terra, para fora da cava' o que ainda não foi descoberto, aquilo que ainda não é conhecido, o que ainda precisa ser desvendado (PAPES, 2002, p. 61).

Através da trajetória do personagem Vítor (re)descobrimos o nosso ser, a nossa verdadeira existência e tendemos a refletir acerca do nosso eu, do modo como construímos nossa identidade, se ela realmente existe, ou se temos, também que encontrar a escada, a rua, cavando, cavando. Pelo viés da imaginação, o tatu Vítor fortalece a essência humana como fonte capaz de transformar o mundo, de reinventá-lo e, por meio dessa luz que está no interior de cada ser-no-mundo, é que potencializamos a obra $O$ sofá estampado, de Lygia Bojunga Nunes, como algo que encerra, na trajetória do personagem Vítor, o autêntico humanismo.

\section{Uma reflexão acerca da construção de identidade através das trajetórias dos personagens Maria, de Corda bamba, e Vítor, de $O$ sofá estampado}

Através da trajetória dos personagens Maria, de Corda bamba, e Vítor, de $O$ sofá estampado, vimos sobressair os elos que aproximam as obras e intensificam em Lygia Bojunga Nunes o gosto por contar a realidade através da imaginação. A realidade que vimos emergir da fantasia é a que nos levará a uma existência social consciente, mostrando-nos as misturas de luz e sombra que tecem nossa vida, nosso interior. Maria e Vítor representam a imagem do ser-no-mundo, aquele que sofre as repressões do tempo, mas que tem mobilidade 
para perseguir sua ascensão. O que está em jogo é o resgate do valor humano acima de qualquer força opressiva.

Como centro do percurso reflexivo, Lygia constitui suas obras pelo viés da imaginação. É nesse universo que conquistamos nossa liberdade e resgatamos nossa identidade. Em Corda bamba, é a 'corda' que leva Maria ao profundo do seu ser e, em O sofá estampado, é o 'túnel' cavado por Vítor que o transporta para o seu interior.

A valorização do humano é tematizada nas obras através de um percurso diferenciado. $\mathrm{Na}$ trajetória de Maria, temos o resgate do ser através de personagens humanos, já, no caminho traçado por Vítor, temos a personificação do humano através do personagem-animal. Um dos efeitos causados pela forma distinta de compor a narrativa é a atenuação dos efeitos causados pelo descortinamento do mundo real em $O$ sofá estampado. Através dessa narrativa, a autora parece preservar ainda mais o universo fantástico do mundo infantil. Ela conserva o caráter lúdico, incentiva a projeção do leitor para o mundo da fantasia e dá asas à imaginação, tudo isso num tempo em que os animais falavam. O mundo sem máscaras apresentado em Corda bamba é estruturado por meio de um contar mais direto, em que a autora confere responsabilidade a quem deve zelar pela preservação e pelo resgate do ser no mundo, confere ao ser da razão o seu papel na sociedade.

Maria e Vítor simbolizam a esperança de um mundo mais humano; Barbuda, Foguinho, a Velha da História, Dona Popô, a Vó do Vítor, especialmente, representam a coletividade que tem luz em seu interior mas que acaba sendo abafada pelo mundo opressivo. Dona Maria Cecília, Dona Eunice, Dalva, a Dona-da-casa, a professora de Vítor são os personagens que elegemos para ilustrar o mundo opressor, aquele destituído de profundidade e que, sem se dar conta, é também fruto da opressão, são os que oprimem e são oprimidos.

Através de uma linguagem simbólica, Lygia leva-nos a perceber a construção dos sentidos ao alcance da representação de elementos como portas, janelas, corda, fio, corredor, cores, túneis, engasgos, vontade de cavar e, aos poucos, vamos passando para o universo da fantasia, do sonho e da imaginação. Vamos tornando-nos capazes de adentrarmos no íntimo do ser devastado por circunstâncias funestas e resgatá-lo para a vida. Através das narrativas, a autora realça os contornos que tendem a abafar o ser; mostra-nos o desnudamento do mundo e do homem; revela traços que denunciam um universo em decadência no que se refere aos valores humanos.

Maria se depara com o mundo real, com a sua superficialidade e não consegue distinguir sua verdadeira face. É um espaço que não oferece espelhos, que apenas reproduz comportamentos estereotipados que não dialogam com a interioridade humana. Maria 
encontra sua verdadeira face através da imaginação e do sonho. Vítor é também tentado pelo mundo real que o quer como ser-objeto, mas sua interioridade o transporta para o mundo da fantasia, o qual proporciona o (re)encontro consigo mesmo. É o mundo da essência, é o mundo que revela o que está escondido, é o mundo que não tem medo de ver e de ser visto, que zela pela integridade humana e que, nos diz, tanto através do percurso de Maria, em Corda bamba, quanto através da trajetória de Vítor, em O sofá estampado, que a possibilidade de ascensão do humano está dentro de cada um de nós e que o caminho para nos enxergarmos por dentro é através da instauração de um mundo que se constrói por meio do sonho, da fantasia e da imaginação.

\section{Considerações finais}

Como norte desse estudo, a trajetória dos personagens Maria, de Corda bamba, e Vítor, de $O$ sofá estampado, de Lygia Bojunga Nunes, motivou nossa investigação acerca das seguintes questões, de caráter abrangente: mundo imaginário versus mundo real, onde está a nossa verdadeira face? E de caráter mais específico: que caminhos o eu percorre para se encontrar e o que ele nos revela a respeito desses caminhos, mundo real versus mundo imaginário? Para tanto, utilizamos leituras que envolvem pesquisas acerca das obras e da autora, como também de teóricos que norteiam nossa visão acerca do que podemos chamar, hoje, de identidade e de como entendê-la no mundo moderno.

Munidos pelos questionamentos e pelas leituras, traçamos um percurso que procura compreender o mundo da fantasia, da imaginação e do sonho como sendo o espaço libertador, o meio pelo qual resgatamos nosso ser, (re)encontramos nossa verdadeira face e somos fortalecidos para prosseguir nossa caminhada. Maria e Vítor personificam o mundo possível e representam a força que reage contra o sistema autoritário, transcendendo o real através da imaginação. É nesse espaço que veremos a instauração dos sentidos através de uma linguagem simbólica que, mais uma vez, reforça o imaginário como espaço propício para a (re)descoberta do eu em relação ao outro, em relação ao mundo da estagnação e da desapropriação do eu de sua essência.

O campo simbólico é o da imaginação, o da liberdade, aquele que simboliza a passagem de Maria e Vítor para uma instância superior e que os leva a uma viagem introspectiva, fazendo-os se depararem com acontecimentos passados à luz da imaginação e, sob esse efeito luminoso, superarem traumas e medos. Assim, voltam ao presente fortalecidos e com a certeza de que o futuro seguirá uma trajetória de possibilidades, de muitas portas e 
janelas, e eles irão abrir todas elas, sem medo, pois são seres capazes de inventar e transformar o mundo.

Através dos caminhos percorridos pelos personagens centrais, vimos florescer dos espaços, real e imaginário, traços peculiares que dizem muito da constituição dos sujeitos que habitam esses universos. No mundo real, deparamo-nos com seres-objetos, frutos de uma sociedade artificializada e capitalista, incapaz de ver e de reconhecer o outro e que está distante de perceber a estagnação que a envolve. Os personagens que integram esse meio personificam a estagnação e sem se notarem são seres manipulados pelo sistema e que tendem a manipulação do outro. Incapazes de se mostrarem, de revelarem sua interioridade, Maria e Vítor, lançam-se para o mundo da imaginação, espaço em que os contornos tecidos pelo mundo real são apagados.

Em essência, percebemos a revelação do verdadeiro eu dos sujeitos através do mundo da imaginação, do sonho e da fantasia. A escritora constituiu uma obra que encerra o universal, que se revela cheia de caminhos e possibilidades, que nos diz das trajetórias de Maria e Vítor como sendo o anuncio de que ainda há esperança para a transformação do mundo através dos sujeitos, através de cada um de nós que, mesmo com medo, com vontade de nos esconder e de sumir, procuramos pelas portas e janelas e acreditamos que surgirão. Sentimos que esse, definitivamente, é o caminho da libertação.

Através desse percurso, nas trajetórias dos personagens Maria, de Corda bamda, e Vítor, de $O$ sofá estampado, procuramos perceber como se revelam os mundos, real e imaginário, na (des)construção da identidade e, especialmente, o que cada um desses universos mostra a respeito do humano, temática central de Lygia Bojunga Nunes nas obras analisadas.

\section{Referências}

BAUMAN, Zygmunt. Amor Líquido: sobre a fragilidade dos laços humanos. MEDEIROS, Carlos Alberto (Trad.). Rio de Janeiro: Jorge Zahar Editor, 2004. 2005.

. Identidade. MEDEIROS, Carlos Alberto (Trad.).. Rio de Janeiro: Jorge Zahar Editor,

BETTELHEIM, Bruno. A psicanálise dos contos de fadas. CAETANO, Arlene (Trad.) 14 ed. Rio de Janeiro: Paz e Terra, 1980.

MACHADO, Ana Maria. O menino que espiava pra dentro. Rio de Janeiro: Nova Fronteira, 1983. 
NETTO, Anderson Pereira da Silva. Literatura infantil: um mergulho no caldeirão da imaginação. Jornal A Página, Rio de Janeiro, ano 13. n. 130, p. 18, jan. 2004.

NUNES, Lygia Bojunga. Corda bamba. 14 ed. Rio de Janeiro: Agir, 1992.

. O sofá estampado. 8 ed. Rio de Janeiro: José Olympio, 1988.

PAPES, Cleide da Costa e Silva. A vivência e a invenção no cotidiano em Rosa, minha irmã Rosa, de Alice Oliveira e O sofá estampado, Lygia Bojunga Nunes. Disponível em: http://www.teses.usp.br/teses. Acessado em 10/03/2008.

PAULI, Alice Atsuko Matsuda. A travessia de Maria: uma experiência de leitura de Corda bamba, de Lygia Bojunga Nunes. Disponível em: http://www.biblioteca.unesp.br/bibliotecadigital. Acessado em 10/03/2008.

MAGALHÃES, Ligia Cademartori. Literatura infantil brasileira em formação. In: ZILBERMAN, Regina; MAGALHÃES, Ligia Cademartori. Literatura Infantil: autoritarismo e emancipação. 3 ed. São Paulo: Ática, 1987. 